\title{
Impact of Uterine Prolapse Surgery on Improvement of Bowel Symptoms
}

\author{
Zulfadli $^{1}$, Amir Fauzi ${ }^{1}$, Azhari ${ }^{1}$, Theodorus ${ }^{2}$ \\ ${ }^{1}$ Department of Obstetrics and Gynecology \\ ${ }^{2}$ Medical and Health Research Unit \\ Faculty of Medicine University of Sriwijaya/ \\ Dr. Mohammad Hoesin Hospital \\ Palembang
}

Dampak Operasi Prolapsus Uteri pada Perbaikan Gejala Sistem Pencernaan

\begin{abstract}
Objective: To find the effectiveness of uterine prolapse surgery in patients with bowel symptoms.

Method: Clinical trial without comparison study of 32 consecutive women who underwent surgery for grade III and IV uterine prolapse with bowel symptoms. Bowel symptoms score was evaluated before and three months after surgery by using the Australian Pelvic Floor Questionnaire. Data was analyzed using SPSS version 20.

Result: There were significant mean differences between bowel symptoms score three months after surgery for grade III and IV uterine prolapse and before surgery although there were patients with persistent symptoms. Bowel symptoms scores include constipation, flatus incontinence, fecal incontinence, fecal urgency, defecation frequency, defecation consistency, incomplete bowel emptying, laxative use, and frequency of defecation disorder score, with $\mathrm{p}<0.001$ and $95 \% \mathrm{CI}$.
\end{abstract}

Conclusion: Uterine prolapse surgery was effective to improve quality of life in grade III-IV uterine prolapse patients with bowel symptoms.

[Indones J Obstet Gynecol 2014; 3: 140-145]

Keywords: bowel symptoms, cystocele, rectocele, uterine prolapse surgery

\begin{abstract}
Abstrak
Tujuan: Untuk menentukan efektivitas operasi prolapsus uteri tingkat III-IV pada penderita dengan gejala sistem pencernaan.

Metode: Uji klinis tanpa pembanding dari 32 penderita prolapsus uteri yang disertai gejala sistem pencernaan yang menjalani operasi prolapsus uteri tingkat III-IV. Gejala sistem pencernaan dievaluasi sebelum dan tiga bulan sesudah operasi prolapsus uteri tingkat III-IV menggunakan kuesioner The Australian Pelvic Floor Questionnaire. Data dianalisis menggunakan SPSS versi 20.

Hasil: Terdapat perbedaan rerata skor gejala sistem pencernaan tiga bulan sesudah operasi prolapsus uteri tingkat III dan IV dengan skor sebelum operasi meskipun masih terdapat penderita dengan gejala menetap. Skor gejala sistem pencernaan meliputi skor konstipasi, inkontinensia flatus, inkontinensia fekal, urgensi fekal, frekuensi defekasi, konsistensi defekasi, gejala kesulitan pengosongan rektum, penggunaan pencahar dan skor frekuensi gangguan defekasi. Hasil dievaluasi dengan nilai $p<0,001$ dan interval kepercayaan 95\%.

Kesimpulan: Operasi prolapsus uteri efektif dalam memperbaiki kualitas hidup penderita prolapsus uteri dengan gejala sistem pencernaan.

[Maj Obstet Ginekol Indones 2014; 3: 140-145]

Kata kunci: gejala sistem pencernaan, operasi prolapsus uteri, rektokel, sistokel
\end{abstract}

Correspondence: Zulfadli. Jln. Hayam Wuruk 122 Bandar Lampung Telephone: 081369281010, Email: fadlydr@gmail.com

\section{INTRODUCTION}

Pelvic floor dysfunction is a disorder occurring in about 1 in 11 women. Pelvic floor dysfunctions include urinary or fecal incontinence, pelvic organ prolapse (cystocele, rectocele, enterocele, and uterine prolapse) and sexual disorders, which commonly occurs in older women. These circumstances cause both physical and psychological effects in women suffering from pelvic floor dysfunction. ${ }^{1,2}$

Complaints arising as a result of pelvic floor dysfunction depend on the abnormalities that appeared. In women with pelvic organ prolapse, the supportive tissue of pelvic organ became weak causing pelvic organs to fall out of its site. Most women are not aware of this disorder until a pelvic organ prolapsed or bulged out of her vagina. Organs that can bulge are uterus (uterine prolapse), bladder (cystocele), urethra (urethrocele), bowel (enterocele) and rectal (rectocele). . $^{3,4}$

Most common complaints causing admission to hospital include bleeding, infection and pain. Meanwhile, the complaints of the disease found were sense of a lump in the vagina, feeling of something coming out from the vagina, low back pain, cystocele, rectocele, coitus difficulty, enterocele, and bowel symptoms such as a bowel movement difficulty, the need to manually evacuate stool, consti- 
pation, incomplete evacuation, fecal urgency, losing control of defecation and flatus, pain with bowel movement, constipation or difficulty to evacuate the feces. ${ }^{5,6}$

It is estimated that the lifetime risk of surgery for prolapse or incontinence was $11.1 \%$. Erman reported cases of genital prolapse in M. Jamil Hospital in Padang for five years (1993-1998) was as many as 94 cases. Kemas A. and Fauzi A performed a 4-year study (1999-2003) reporting 43 cases of uterine prolapse in Moh. Hoesin Hospital, Palembang and based on the degree of uterine prolapse, most patients were grade III $(76.74 \%)$ followed by grade II $(18.60 \%)$ and grade I $(4.65 \%))^{7,8}$

Vaginal hysterectomy is a useful operation that can reduce complaints or symptoms of bowel disorder that usually accompanies uterine prolapse. Miedel et al reported a 1-year follow-up after uterine prolapse surgery in 61 patients with bowel symptoms (difficulty on defecation, fecal incontinence and flatus) in which $75 \%$ (95\% CI 64-87) experienced a reduction in bowel symptoms. In the follow-up of 5 years, 49 of 61 patients were evaluated and $55.1 \%$ (27 of 49 patients) became asymptomatic. $^{9}$

Although many literature have discussed the effects of bowel symptoms on women's quality of life but very few data is available on the prevalence of bowel symptoms in patients with grade III-IV uterine prolapse and the effectiveness of surgery in grade III-IV uterine prolapse in reducing or eliminating bowel symptoms.

\section{METHODS}

After obtaining approval from the institutional review board at Universitas Sriwijaya, we collected patients who underwent surgery for grade III and IV uterine prolapse with bowel symptoms between July 2011 and December 2012 as target population. The method for sampling was consecutive sampling. Patients who met the inclusion criteria were given explanation of participation in research and signed informed consent.

Our exclusion criteria were diseases related to uterine prolapse as well as pre-existing intestinal disorders such as irritable bowel syndrome, diarrhea, systemic disease such as diabetes mellitus, stroke, previous history of spinal cord injury, and use of estrogen.
All collected samples were interviewed to assess demographic characteristics of the subjects as well as bowel symptoms by using questionnaire from the Australian Pelvic Floor Questionnaire. Gynecologic examination was performed and the classification of uterine prolapsed by POP-Q system was used to establish the degree of uterine prolapse. Subjects were given questionnaires regarding bowel symptoms to assess the various bowel symptoms they feel associated with uterine prolapse grade III-IV. Uterine prolapse surgery was performed by a urogynecologist. Three months after the operation, we repeated the same questionnaire.

The results were then compared using paired ttest to analyze bowel symptoms before and after uterine prolapse grade III-IV surgery. All data were analyzed using statistical data processing program SPSS for Windows version 20.

\section{RESULTS}

In this study, 32 of 38 women who underwent surgery for grade III and IV uterine prolapse in the period of July 2011 up to December 2012 met the inclusion criteria.

Distribution of age was mostly in the range of over 60 years, 19 subjects (59.4\%) with a mean age of 61.668 .02 years (Table 1). The Body Mass Index (BMI) of most subjects ranged from 18.5 to $25.0(84.4 \%)$ with a mean of 22.652 .30 .

There were 20 subjects (62.5\%) with grande multiparity, 10 subjects (31.3\%) with multiparity and 2 subjects (6.3\%) were nullipara. A total of 27 subjects (84.4\%) had no history of previous illnesses, while the rest of the subjects had previous history of hypertension. All subjects had no history of previous surgery.

The most common degree of uterine prolapse was grade IV in 21 subjects (65.6\%) and grade III in 11 subjects $(34.4 \%)$.

Rectocele degree found in our subjects were grade II $(62.5 \%)$ followed by grade III $(18.8 \%)$, grade I $(15.6 \%)$ and grade IV (3.1\%). The most commonly found cystocele degree was grade II in 16 subjects $(50.0 \%)$.

There were 31 subjects $(96.87 \%)$ who scored lower constipation symptoms three months after uterine prolapse surgery compared with before surgery with a mean difference of $2.16 \quad 0.80$ $(p<0.001)$. Only one subject $(3.13 \%)$ had a constant 
score. All of our subjects reported lower flatus incontinence symptom scores three months after uterine prolapse surgery compared with before surgery with a mean difference $1.38 \quad 0.09$ (p $<0.001)$. In 28 subjects (87.5\%) fecal incontinence symptom score was lower three months after uterine prolapse surgery compared with before surgery with a mean difference of $1.63 \quad 0.18$ (p $<0.001$ ), while the remaining four subjects maintained the same score.

Table 1. Demographic Characteristic of Subjects.

\begin{tabular}{|c|c|c|}
\hline \multirow{2}{*}{ Characteristic } & \multicolumn{2}{|c|}{ Frequency } \\
\hline & $\mathbf{n}$ & $\%$ \\
\hline \multicolumn{3}{|l|}{ Age (years) } \\
\hline 60 & 13 & 40.6 \\
\hline$>60$ & 19 & 59.4 \\
\hline \multicolumn{3}{|l|}{ Body Mass Index $\left(\mathrm{kg} / \mathrm{m}^{2}\right)$} \\
\hline $18.5-25.0$ & 27 & 84.4 \\
\hline $25.0-27.0$ & 1 & 3.1 \\
\hline$>27.0$ & 4 & 12.5 \\
\hline \multicolumn{3}{|l|}{ Parity } \\
\hline Nulliparity & 2 & 6.3 \\
\hline Multiparity & 10 & 31.3 \\
\hline Grande Multiparity & 20 & 62.5 \\
\hline \multicolumn{3}{|c|}{ Degree of uterine prolapse } \\
\hline III & 11 & 34.4 \\
\hline IV & 21 & 65.6 \\
\hline \multicolumn{3}{|l|}{ Degree of cystocele } \\
\hline I & 2 & 6.3 \\
\hline II & 16 & 50.0 \\
\hline III & 14 & 43.6 \\
\hline \multicolumn{3}{|l|}{ Degree of rectocele } \\
\hline I & 5 & 15.6 \\
\hline II & 20 & 62.5 \\
\hline III & 6 & 18.8 \\
\hline IV & 1 & 3.1 \\
\hline \multicolumn{3}{|l|}{ Surgery technique } \\
\hline TVH & 1 & 3.15 \\
\hline $\mathrm{TVH}+\mathrm{AC}$ & 9 & 28.1 \\
\hline $\mathrm{TVH}+\mathrm{AC}+\mathrm{PC}$ & 13 & 40.6 \\
\hline TVH + colpocleisis & 8 & 25 \\
\hline Colpocleisis & 1 & 3,15 \\
\hline
\end{tabular}

$T V H=$ Total Vaginal Hysterectomy, $A C=$ Anterior Colporraphy, $P C=$ Posterior Colporraphy.
A total of 26 subjects (81.25\%) had lower fecal urgency symptom score three months after uterine prolapse surgery compared with before surgery with a mean difference of $1.28 \quad 0.14(\mathrm{p}<0.001)$, while 6 subjects (18.75\%) still had the same score. There were 28 subjects $(87.5 \%)$ who had lower defecation frequency score after uterine prolapse surgery with a mean difference of 1.190 .15 (p $<0.001$ ). Half of our subjects had lower bowel consistency score three months after uterine prolapse surgery, and the mean difference was $0.57 \quad 0.11$ $(p<0.001)$, while the rest of the subjects retained the same score.

Almost all of our subjects (93.75\%) showed improvements in score for difficulty in emptying the rectum after the surgery compared with before surgery with a mean score of $3.16 \quad 1.94$ and 6.75

2.64 respectively. Scores for laxative use was also lower after surgery in more than $90 \%$ of respondents. The mean difference of laxative use score was $1.530 .14(\mathrm{p}<0.001)$. As much as $87.5 \%$ of our sample had a lower post-operative frequency defecation disorders score compared with the preoperative score with $1.41 \quad 0.15$ mean difference $(\mathrm{p}<0.001)$

\section{DISCUSSION}

Distribution of age in this study was similar to the incidence of uterine prolapse in research conducted by Hove et al, which reported that women with grade III-IV uterine prolapse were 45-84 years on average. ${ }^{10}$ Khan et al reported the median age of women suffering from uterine prolapse was 56 years (range $=19-94$ years). ${ }^{11}$ Nygaard et al reported that uterine prolapse was found in the age of 20-80 years but most cases were found at age 40-59 years. ${ }^{12}$ Distribution of age in this study is suitable with the important factors underlying uterine prolapse. With increasing age, the incidence of uterine prolapse would increase as well because the ligaments, pelvic floor muscles, pelvic organs and supporting fascia will be weakened. ${ }^{13}$

The distribution of BMI in this study is not much different from the samples in the study by Hove et al, where the BMI was $25.6 \mathrm{~kg} / \mathrm{m}^{2}$ on average. ${ }^{10}$ Khan et al reported the median BMI of women with uterine prolapse was $27 \mathrm{~kg} / \mathrm{m}^{2}{ }^{11}$ Nygaard et al reported uterine prolapse were most common at the level of BMI $>30 \mathrm{~kg} / \mathrm{m}^{2}$ followed with $\mathrm{BMI}<25.0$ $\mathrm{kg} / \mathrm{m}^{2}$. In several studies, uterine prolapse was most often found in the obese patient, which was 
Table 2. Effectiveness analysis of uterine prolapsed surgery grade III-IV in patients with bowel symptoms.

\begin{tabular}{|c|c|c|c|c|c|c|}
\hline Analysis & $\mathbf{n}$ & Mean & SD & $\begin{array}{c}\text { Mean } \\
\text { Differences }\end{array}$ & CI 95\% & $\mathbf{p}$ \\
\hline Constipation score before surgery & 32 & 2.56 & 0.50 & 2.160 .80 & $1.87-2.45$ & $<0.001$ \\
\hline Constipation score three month after surgery & 32 & 0.41 & 0.56 & & & \\
\hline Flatus incontinence score before surgery & 32 & 1.69 & 0.78 & 1.380 .09 & $1.18-1.58$ & $<0.001$ \\
\hline Flatus incontinence score three month after surgery & 32 & 0.31 & 0.54 & & & \\
\hline Fecal incontinence score before surgery & 32 & 2.94 & 1.65 & 1.630 .18 & $1.26-1.99$ & $<0.001$ \\
\hline Fecal incontinence score three month after surgery & 32 & 1.31 & 0.97 & & & \\
\hline Fecal urgency score before surgery & 32 & 1.59 & 1.07 & 1.280 .14 & $0.99-1.58$ & $<0.001$ \\
\hline Fecal urgency score three month after surgery & 32 & 0.31 & 0.47 & & & \\
\hline Frequency of defecation score before surgery & 32 & 1.41 & 0.67 & 1.190 .15 & $0.96-1.42$ & $<0.001$ \\
\hline Frequency of defecation score three month after surgery & 32 & 0.22 & 0.42 & & & \\
\hline Consistency of defecation score before surgery & 32 & 0.75 & 0.72 & 0.570 .11 & $0.34-0.79$ & $<0.001$ \\
\hline Consistency of defecation score three month after surgery & 32 & 0.19 & 0.39 & & & \\
\hline Incomplete bowel emptying score before surgery & 32 & 6.75 & 2.64 & 3.591 .79 & $2.94-4.24$ & $<0.001$ \\
\hline Incomplete bowel emptying score three month after surgery & 32 & 3.16 & 1.94 & & & \\
\hline Laxative use score before surgery & 32 & 2.00 & 0.76 & 1.530 .14 & $1.26-1.81$ & $<0.001$ \\
\hline Laxative use score three month after surgery & 32 & 0.47 & 0.67 & & & \\
\hline Frequency of defecation disorder score before surgery & 32 & 1.88 & 0.98 & 1.410 .15 & $1.11-1.71$ & $<0.001$ \\
\hline Frequency of defecation disorder score three month after surgery & 32 & 0.47 & 0.62 & & & \\
\hline
\end{tabular}

Paired $t$-test, $p<0.001$

contradictive with the distribution of BMI in this study where the majority had normal BMI. Thus, it can be concluded that in this study BMI is less likely to play a role in the occurrence of uterine prolapse. $^{13}$

We found that the most common parity status in our sample was grande-multiparity, in line with reports by Junizaf et al, where the prevalence of uterine prolapse increased with age with a mean age of 60-70 years and parity of more than three. ${ }^{1}$

Burrow and Hove reported women with mild (grade I) or moderate (grade II) prolapse might have no complaint. Usually complaints occur after the patient has developed a third of forth degree uterine prolapse. Pelvic organ prolapse can occur due to aging, lack of estrogen and collagen density, obesity, chronic cough and chronic constipation causing weakness of supporting tissue or muscles or a combination of both. Endopelvic fascia weakness causes a protrusion of soft tissue through the vaginal wall. Supporting tissue damage, which was disputed by the endopelvic fascia tissue damage is then produced. Endopelvic fascia weakness also causes trauma of the neural muscles supporting the pelvic floor. 4

Epidemiological studies in the general population conducted by Eva et al reported symptoms of uterine prolapse varying from heavy feeling in the genitals, the need to push the perineum or vagina to help defecation, feeling of something coming out from the vagina, low back pain, cystocele, rectocele, intercourse difficulty, enterocele, until walking difficulties. In uterine prolapse accompanied by rectocele, bowel symptoms like constipation, flatus incontinence, fecal incontinence, fecal urgency, and difficulty emptying the rectum can usually be found. ${ }^{14}$

Overall, subjects in this research underwent spinal anesthesia. Spinal anesthesia is often chosen because of its practicality, rapid onset, and better blockade causing its frequent use in obstetric surgeries. Selection of the operation technique was 
based on the severity of pelvic organ prolapse. Most often, the surgery performed in our study was total vaginal hysterectomy (TVH) because of the ability to conduct anterior colporraphy and colpoperineorraphy at the same time. The main advantage of vaginal hysterectomy is the reduced surgery incision, limiting trauma to the pelvic peritoneum and consequently less risk of hemorrhagic shock and less postoperative pain. ${ }^{15}$

Our results are not much different from the study by Ashby et al, who found that about $72 \%$ of the sample experienced improvement of symptoms of constipation one year after uterine prolapse surgery, while the rest have persistent symptoms. Meanwhile, Sung et al reported one year after operation of uterine prolapse accompanied by rectocele, approximately $60.6 \%$ of patients experienced resolution of constipation symptoms, $22.7 \%$ of patients had persistent symptoms, $16.7 \%$ of patients experienced a reduction in symptoms. ${ }^{16}$

Research conducted by Steinberg et al reported patients with flatus incontinence had a $90 \%$ reduction in symptoms six months after uterine prolapse surgery. Patients with flatus incontinence is often accompanied by symptoms of fecal incontinence. ${ }^{17}$ The results was not much different from the study by Ashby et al where one year after surgery for uterine prolapse, $92 \%$ of patients experienced improvement of fecal incontinence symptoms. In the same study, fecal urgency symptoms were resolved in $54 \%$ of patients one year after surgery for uterine prolapse while $26 \%$ of patients had persistent symptoms. ${ }^{16}$

Sung et al reported that one year after uterine prolapse surgery in patients complicated with rectocele, resolution of symptoms was found in $50 \%$ of patients, $23 \%$ experienced a reduction in symptoms, $19 \%$ had persistent symptoms and $8 \%$ de novo. ${ }^{18}$

Management of genital prolapse is individualized, especially in those who had complaints and complications, but in general management is comprised into two ways, conservative and operative. ${ }^{19,20}$

In patients with uterine prolapse grade III and IV with bowel symptoms, it is recommended to perform total vaginal hysterectomy and anterior or posterior colporraphy to reduce or eliminate bowel symptoms of constipation, flatus incontinence, fecal incontinence, fecal urgency, difficulty in empty- ing the rectum, the use of laxatives or symptoms associated with defecation disorders.

Further study is required to examine the effectiveness of different types of surgery in patients with bowel symptoms. This can aid in the consideration of which operating technique can improve and relieve persistent bowel symptoms.

\section{CONCLUSION}

Bowel symptoms were found in all patients with uterine prolapse grade III and IV, ranging from constipation, flatus incontinence, fecal incontinence, fecal urgency, frequency of defecation, consistency of bowel movements, symptoms of rectal emptying difficulties, use of laxatives and the frequency of defecation disorders. Uterine prolapse surgery was effective in improving quality of life in uterine prolapse patients with bowel symptoms.

\section{REFERENCES}

1. Rizkar M. Prolapsus uteri. In: Junizaf, Santoso BI, editors. Buku ajar uroginekologi Indonesia. Himpunan Uroginekologi Rekonstruksi Indonesia. Jakarta: Himpunan Uroginekologi Indonesia Bagian Obstetri Ginekologi FKUI; 2011: 29-37.

2. Rivlin ME. Prolapse. In: Rivlin ME, Martin RW, eds. Manual of clinical problems in obstetrics and gynecology. $5^{\text {th }}$ ed. Philadelphia: Lippincott Williams and Wilkins; 2008: 241-4.

3. Walker GJ, Gunasekera P. Pelvic organ prolapse and incontinence in developing countries: review of prevalence and risk factors. Int Urogynecol J 2010: 1-9.

4. Burrows LJ, Meyn LA, Walters MD et al. Pelvic symptoms in women with pelvic organ prolapse. Am J Obstet Gynecol 2004; 104(5): 982-8.

5. Ha K, Danez C, Nelken R, et al. Colorectal and anal symptoms in women with urinary incontinence and pelvic organ prolapse. Int Urogynecol J 2010; 21: 187-91.

6. Khan RF, Cunkelman J, Lowenstein L et al. Prevalence of bowel symptoms in women with pelvic floor disorders. Int Urogynecol J 2010; 21: 933-8.

7. Erman, Bakar E. Gambaran prolapsus genitalia di RSUP dr. M. Jamil Padang selama lima tahun. Maj Obstet Ginekol Indones, 2001; 25: 92.

8. Anhar K, Fauzi A. Kasus prolapsus uteri di Rumah Sakit dr. Mohammad Hoesin Palembang selama lima tahun (19992003). Palembang: Bagian/Departemen Obstetri dan Ginekologi Fakultas Kedokteran Universitas Sriwijaya/RSMH Palembang. 2003.

9. Miedel A, Tegerstedt G, Morlin B et al. A 5-year prospective follow-up study of vaginal surgery for pelvic organ prolapse. Int Urogynecol J 2008; 19: 1593-601.

10. Hove MC, Goudzwaard AL, Eijkemans MJ et al. The prevalence of pelvic organ prolapse symptoms and signs and their relation with bladder and bowel disorders in a general female population. Int Urogynecol J 2009; 20: 1037-45. 
11. Khan FR, Cunkelman J, Lowenstein L et al. Prevalence of bowel symptoms in women with pelvic floor disorders. Int Urogynecol J 2010; 21: 933-8.

12. Nygaard I, Barber MD, Burgio KL [Online]. Prevalence of symptomatic pelvic floor disorders in US women. American Medical Association. 2008 [cited 2008 Sept 24]. Available from:http://jama.ama-assn.org/cgi/content/full/300/11/ 1311.

13. Wasserberg N, Haney M, Petrone $P$ et al. Fecal incontinence among morbid obese women seeking for weight loss surgery: an underappreciated association with adverse impact on quality of life. Int J Colorectal Dis 2008; 23: 493-7.

14. Eva UF, Gun W, Preben K. Prevalence of urinary and fecal incontinence and symptoms of genital prolapse in women. Acta Obstet Gynecol Scand 2003; 82: 280-6.

15. Dam JH, Gosselink MJ, Drogendijk AC et al. Changes in bowel function after hysterectomy: University Hospital Dijkzigt, Rotterdam. 2007; 40(11): 1342-7.
16. Ashby AM, Paraiso MF, Jelovsek JE et al. Bowel symptoms 1 year after surgery for prolapse: further analysis of a randomized trial of rectocele repair. Am J Obstet Gynecol 2007; 18: 76.e1-5.

17. Steinberg AC, Collins SA, O'Sullivan DM. The impact of flatal incontinence on quality of life. Am J Obstet Gynecol 2009; 201: 539.e1-3.

18. Sung VW, Rardin CR, Raker CA, et al. Changes in bowel symptoms 1 year after rectocele repair. Am J Obstet Gynecol 2012; 207: 423.e1-5.

19. Sanz LE. My approach to surgical correction of total uterovaginal prolapse. Contemp Obstet Gynecol 1998: 1-11.

20. Karell SA. Nonsurgical management of pelvic organ prolapse. In: Bent AE, Curdiff GW, Ostergard DR, Swift SE. Eds. Ostergard's urogynecology and pelvic floor dysfunction. Philadelphia: Lippincot Williams \& Wilkins, 2007: 393. 